\title{
Pengembangan Produk Sumber Tenaga Listrik Mini Dengan Pendekatan VDI (Verein Deutscher Ingeniure) 2221
}

\author{
Albertus L. Setyabudhi ${ }^{(1)}$, Ganda Sirait ${ }^{(2)}$ \\ ${ }^{(1)}$ Sekolah Tinggi Teknik Ibnu Sina, ${ }^{(2)}$ Universitas Putera Batam \\ ${ }^{(1)} \mathrm{Jl}$. Teuku Umar, Lubuk Baja; ${ }^{(2)} \mathrm{Jl}$. Raya Tembesi, Batu Aji \\ (1)albertlssby@gmail.com; ${ }^{(2)}$ ganda.srt@gmail.com
}

\begin{abstract}
ABSTRAK
Pembangkit listrik dengan bahan bakar alternatif menjadi trend saat sekarang ini. Belum ada pembangkit listrik dengan bahan bakar alternatif untuk skala rumah tangga. Padahal energi listrik saat ini merupakan salah satu kebutuhan utama dalam kegiatan rumah tangga. Sehingga perlu terobosan untuk membuat pembangkit listrik mini yang dapat digunakan oleh rumah tangga. Dengan pengembangan produk maka penelitian kali ini akan membuat pembangkit listrik mini. Penelitian pengembangan produk ini dilakukan hingga tahap product design. Pada tahap pertama pengembangan produk dilakukan identifikasi kebutuhan pengguna dengan menggunakan house of quality. Dilanjutkan dengan pelaksanaan tahap kedua yaitu product design yang dilakukan dengan metode VDI (Verein Deutscher Ingeniure) 2221. Dengan menggunakan sumber dari motor DC untuk menghasilkan energi listrik diharapkan hasil perancangan ini dapat digunakan oleh rumah tangga di pulau-pulau terpencil di Kepulauan Riau yang belum terjangkau atau bahkan daerah yang terisolir. Alat ini memiliki skema pengembangan dari arus direct current (DC) $12 \mathrm{~V}$ sehingga dapat menghasilkan output 220 V alternative current $(A C)$ dengan daya 500 watt melalui rangkaian magnet permanen. Sehingga dari perancangan produk ini muncul sumber energi listrik alternatif terbarukan dan ramah lingkungan yang selanjutnya dapat dikembangkan bersama dengan industri yang ada.
\end{abstract}

Kata Kunci- Pengembangan produk, product design, pembangkit listrik mini, bahan bakar alternatif, ramah lingkungan

\section{PENDAHULUAN}

Penggunaan Bahan Bakar Minyak dan Batu Bara telah menjadi kontroversi dalam era modernisasi saat ini. Pada saat ini teknologi pembangkit listrik sudah banyak diarahkan menggunakan sumber tenaga yang lain sebagai alternatif seperti misalnya air, udara, nuklear, matahari dan yang terbaru dengan menggunakan minihidro. Tetapi semua sumber tenaga diatas membutuhkan tempat dan biaya yang cukup besar sebanding dengan energi listrik yang dihasilkan. Perlu dilakukan pengembangan produk sehingga dapat membuat sumber tenaga listrik mini yang dapat digunakan pada rumah tangga.

Tujuan dari penelitian ini adalah dapat menghasilkan sumber tenaga listrik mini sederhana yang dapat digunakan oleh masyarakat dalam skala rumah tangga. Dengan adanya penelitian ini diharapkan ada pengembangan teknologi dalam sumber tenaga listrik.

\section{TINJAUAN PUSTAKA}

Dalam kehidupan sehari-hari listrik sudah menjadi sebuah kebutuhan pokok bagi kehidupan rumah tangga. Apabila tidak ada energi listrik maka serasa kehidupan menjadi lumpuh. Seiring dengan berkembangnya dunia industri maka kebutuhan akan penggunaan listrik menjadi lebih banyak lagi. Hal ini mengakibatkan harga jual listrik menjadi semakin mahal. Oleh karena itu maka diperlukan terobosan baru untuk mendapatkan energi listrik yang lebih murah.

Pada dasarnya semua energi listrik diperoleh dengan menggunakan medan magnet oleh karena itu muncullah mesin yang disebut generator, dimana tujuan dari mesin ini adalah mengubah medan magnet yang ada menjadi energi listrik. Pengubahan tersebut dilakukan dengan cara menggerakan magnet yang ada sehingga gerakan tersebut dapat mengubah medan magnet yang ada menjadi 
energi listrik. Dan yang menjadi sumber energi untuk menggerakan magnet tersebut dapat diperoleh dari gerakan apa saja seperti air, angin, uap, dll.

Dalam penelitian ini penulis hendak membuat sumber energi listrik mini yang dapat digunakan untuk membantu rumah tangga dalam mendapatkan energi listrik yang murah. Tentunya sumber energi ini menggunakan beberapa rangkaian untuk menghasilkan energi listrik yang dibutuhkan.
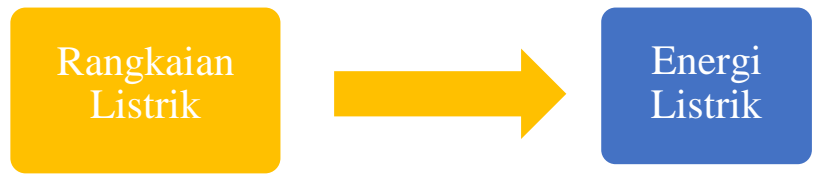

Gambar 1. Skema Konsep Sumber Listrik

Kerangka pemikiran adalah suatu diagram yang menjelaskan secara garis besar alur logika berjalannya sebuah penelitian. Kerangka pemikiran dibuat berdasarkan pertanyaan penelitian dan merepresentasikan suatu himpunan dari beberapa konsep serta hubungan diantara konsep-konsep tersebut. (Sugiyono, 2013).

Langkah-langkah perancangan pengembangan produk sumber energi listrik ini, dapat dijelaskan juga dalam bentuk alur diagram dibawah ini.

\section{Product Planning}

Product Design

Process Planning

Process Control

Gambar 2. Stage Of The Product Development (Rosenthal, 1992)

Dalam penelitian kali ini perancangan pengembangan produk yang dilakukan hanya sampai tahap kedua dimana disana melakukan product design yang mana dilakukan matching antara design requirements dan part design.

\section{METODE PENELITIAN}

Kerangka kerja yang dilakukan dalam penelitian ini dapat dilihat pada gambar 3 berikut ini:

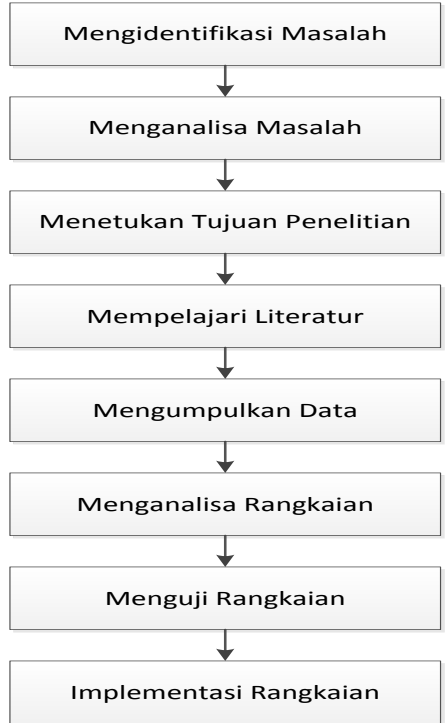

Gambar 3. Kerangka Kerja Penelitian

Dalam pelaksanaan tahap kedua dalam pengembangan produk diatas peneliti menggunakan pendekatan dengan metode VDI 2221. Proses mendesain produk adalah salah satu cabang dari 
rekayasa dan rancang bangun yang banyak bermanfaat dalam menyelesaikan berbagai kebutuhan akan produk yang memenuhi kriteria dan keinginan konsumen.

Mendesain sebuah produk berarti menjabarkan ide yang dimiliki untuk menyelesaikan suatu masalah. Ide, bagaimanapun merupakan otak dari pekerjaan mendesain. Setelah ide didapat, yang menjadi pertanyaan berikutnya adalah metode apa yang akan dipakai dalam mewujudkan ide tersebut hingga menghasilkan sebuah karya yang riil dan dapat dipertanggung-jawabkan secara ilmiah. Hal inilah yang menjadi pemikiran para insinyur dari Jerman untuk membuat metode perancangan produk yang dikenal dengan metode VDI 2221 yaitu pendekatan sistematik terhadap desain untuk sistem teknik dan produk teknik yang dijabarkan oleh G. Pahl dan W. Beitz (VDI = Verein Deutscher Ingeniure/Persatuan Insinyur Jerman).

Langkah kerja yang ada di Metode VDI adalah sebagai berikut:

A. Penjabaran tugas

B. Perancangan konsep

1. Menentukan fungsi dan strukturnya,

a. Struktur fungsi keseluruhan,

b. Sub fungsi.

2. Mencari prinsip solusi dan strukturnya,
a. Metode konvensional,
b. Metode intuitif,
c. Metode diskurtif,
d. Metode kombinasi.

3. Menguraikan menjadi varian yang dapat direalisasikan (Pemilihan kombinasi yang sesuai).

a. Pembuatan varian konsep,

b. Evaluasi.

C. Perancangan wujud

D. Perancangan detail

Langkah kerja tersebut dijabarkan dengan diagram alir seperti yang nampak pada gambar 4. berikut ini.

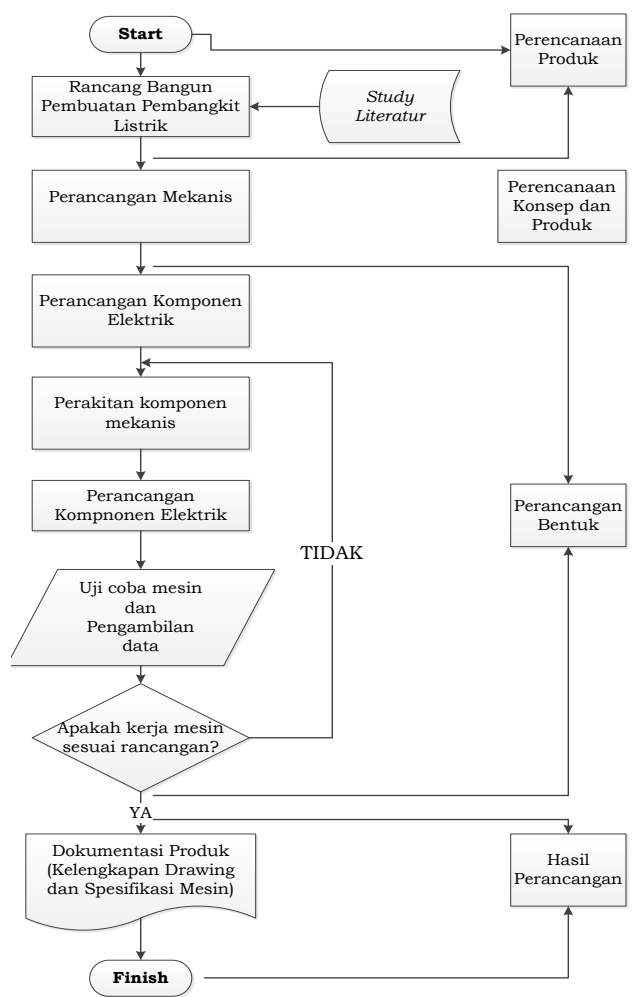

Gambar 4. Diagram alir penelitian 


\section{HASIL DAN PEMBAHASAN}

Tahap awal pengembangan produk adalah melakukan perencanaan produk (product planning), pada tahap ini mencari apa yang dibutuhkan dan diinginkan oleh pengguna produk (Rosenthal, 1992). Selanjutnya kebutuhan pengguna produk akan menjadi acuan untuk spesifikasi design produk yang akan dibuat. Hubungan antara kebutuhan pengguna dengan spesifikasi design produk yang dikembangkan dapat dilihat pada gambar 5. Identifikasi kebutuhan pengguna tersebut peneliti menggunakan house of quality sebagai metodenya.

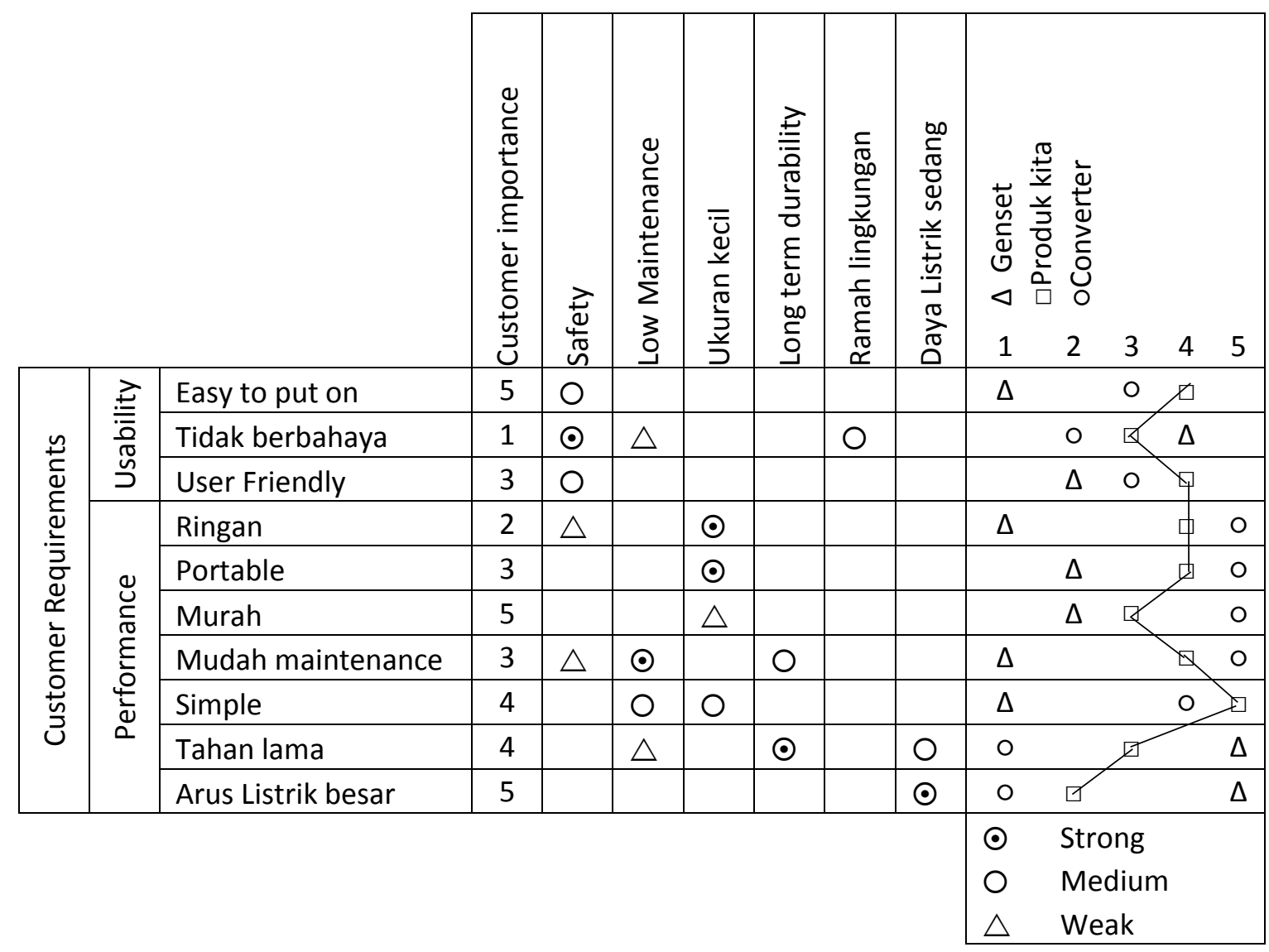

Gambar 5. House of Quality (Customer requirements - Technical description)

Selanjutnya spesifikasi design produk yang sudah didapat dikembangkan hingga menjadi wujud yang real, dimana langkah kerja design produk hingga memiliki wujud yang real menggunakan metode VDI 2221. Konsep yang dirancang awal dapat dilihat pada gambar 1. Dari konsep awal itu terus dikembangkan sesuai dengan struktur dan fungsinya sehingga diperoleh skema blok rangkaian pada gambar 6 .

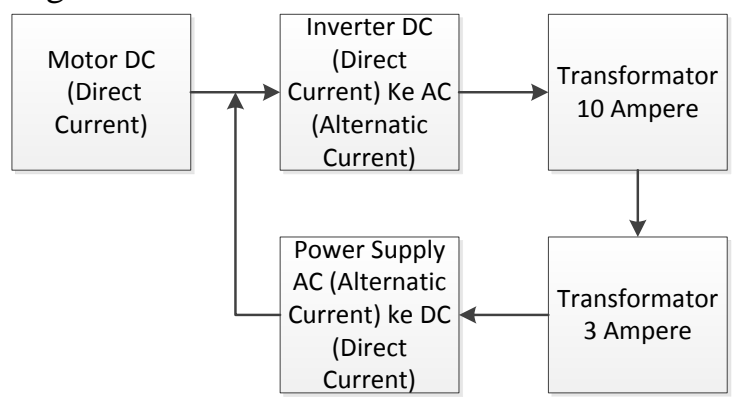

Gambar 6. Skema blok rangkaian 
Dari gambar 6 diatas dilakukan pemilihan bahan yang akan digunakan untuk membuat produk pada tahap perancangan wujud. Adapun bahan yang dipilih adalah dalam tahap menguraikan menjadi vairan yang dapat direalisasikan antara lain adalah :

2 motor DC, dengan memanfaatkan dua buah motor dc yang saling terhubung kita bisa memicu arus dengan arus 12 volt DC. Prinsip kerja yang diambil berdasarkan teori tentang motor DC bahwa ketika kita memberikan arus $12 \mathrm{~V}$ pada motor A, maka polaritas pada motor B akan berubah pada motor DC tersebut. Yang semula pada motor A polaritas + berwarna merah pada motor B akan berubah polaritas menjadi - demikian juga sebaliknya.

Transformator, untuk mengubah tegangan yang akan dikeluarkan oleh produk yang kita buat.

Rangkaian listrik, yang berisi IC, FET, dan komponen-komponen kecil lainnya untuk membantu hasil yang dibutuhkan pada produk yang akan dibuat. Dari bahan-bahan yang digunakan dirangkai sehingga diperoleh wujud produk yang dapat dilihat pada gambar 7 dibawah ini.
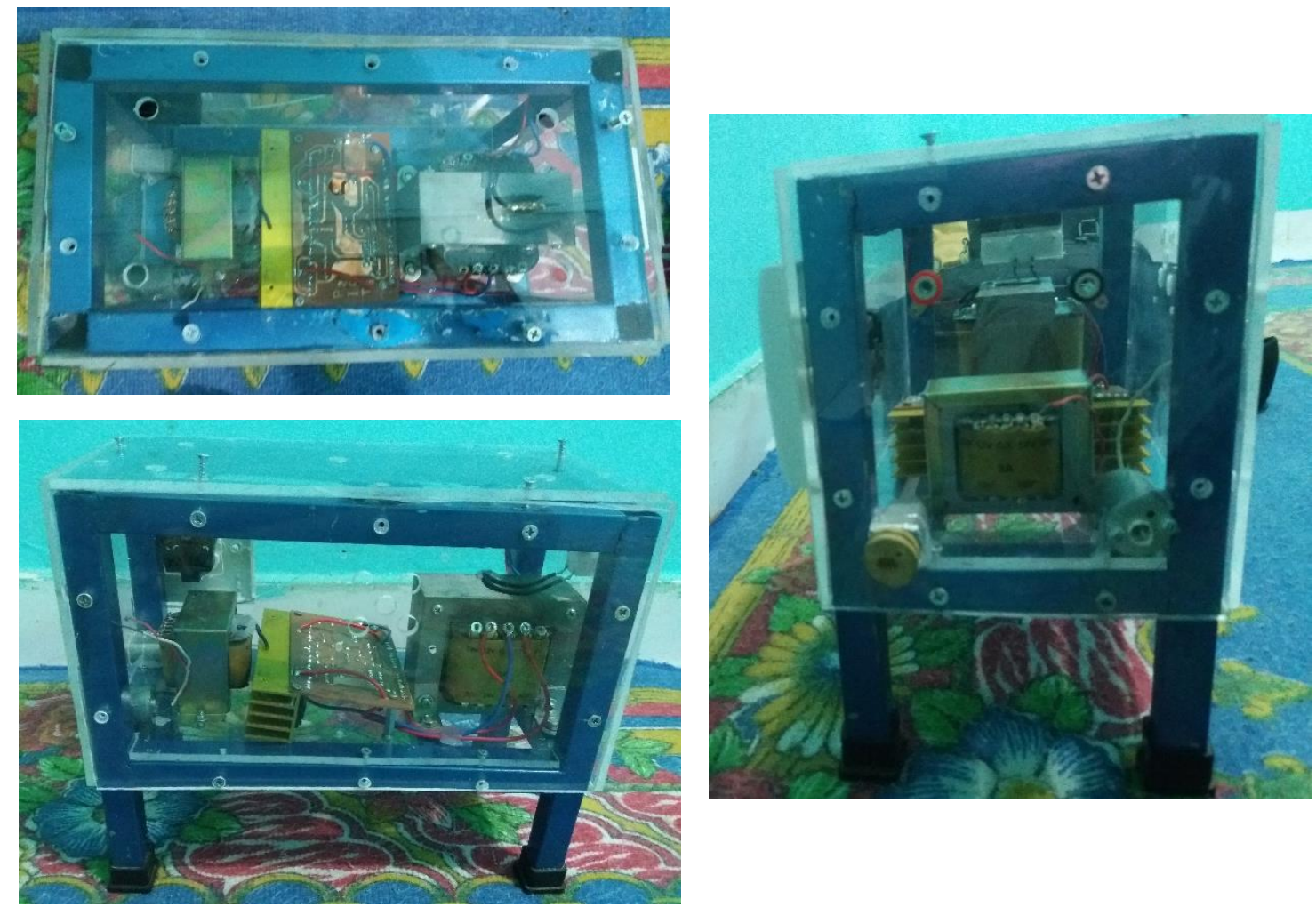

Gambar 7. Wujud produk real

\section{SIMPULAN DAN SARAN}

Berdasarkan hasil penelitian yang diperoleh, maka penulis membuat beberapa simpulan, sebagai berikut:

1. Untuk memperoleh penghasil sumber energi listrik mini dengan memanfaatkan prinsip kerja dari motor berdasarkan literature yang ada, penulis mengembangkan rangkaian agar bisa dimanfaatkan menjalankan peralatan elektronik rumah tangga seperti kipas angin, lampu dan lain-lain. Arus yang dihasilkan dari pengembangan alat tersebut adalah 220 VAC dengan daya maksimum 500 Watt.

2. Asas untuk membantu mengembangkan teknologi sumber listrik.

Sebagai sumber energi altenatif terbarukan dan ramah lingkungan yang bisa diterapkan di masyarakat. Dengan memanfaatkan prinsip kerja dari elektromagnetik penulis bisa merancang dan mengimplementasikan peralatan tersebut dengan hasil yang sempurna dan bermanfaat untuk peralatan elektronik rumah tangga. 
3. Produk ini mendukung ketersediaan sumber energi yang murah dan mendukung inovasiinovasi baru untuk menyediakan energi selain menggunakan BBM.

Saran yang dapat diberikan oleh peneliti untuk penelitian kedepan adalah:

1. Untuk mendapatkan hasil penelitian maksimal perlu dimanfaatkan beberapa literatur sebagai tahap awal dalam perencanaan dan perancangan rangkaian

2. Setelah dilakukan beberapa penerapan dan pengembangan dari beberapa tutorial yang didapatkan dari internet, banyak skema rangkaian yang tidak sesuai dengan hasil yang ada pada tutorial tersebut.

3. Perlu kerjasama dan dukungan dari industri dan masyarakat untuk mewujudkan implementasi sumber energi terbarukan dimasa yang akan datang.

\section{DAFTAR PUSTAKA}

A.J. Dirksen, 1982, Pelajaran Elektronika Jilid 1, Penerbit Erlangga, Jakarta

Erhaneli \& Ferdinal Rutaf, Pembangkit Tenaga Listrik Minihidro di Desa Guguak Ampek Kandang Kecamatan 2X11 Kayu Tanam Kabupaten Padang Pariaman, Jurnal Teknik Elektro Vol. 2 No. November 2013

Herman DS. (1996). Elektronika: Teori dan Penerapan. Yogyakarta: FPTK IKIP Yogyakarta

Herjanto, E., (2007). Manajemen Operasi. Jakarta: Grasindo

H. Muh. Syahrir Habiba \& F. Cahyadi Suryani, Analisis Efektifitas Sistem Pembangkit Listrik Tenaga Gas dan Uap (PLTGU) pada PT. Energi Sengkang, Jurnal ILTEK Vol. I No. 2, April 2006

Ihfazh Nurdin Eka Nugraha, Waluyo \& Syahrial, Penerapan dan Analisis Pembangkit Listrik Tenaga Pikohidro dengan Turbin Propeller Open Flume TC 60 dan Generator Sinkron Satu Fasa 100 VA di UPI Bandung, Jurnal Reka Elkomika 2337-439X, Oktober 2013.

Kountur, Ronny. 2007. Metode Penelitian; Untuk Penulisan Skripsi dan Tesis. Jakarta: PPM.

Malvino, Albert Paul. 1993. Electronic Principles 5th Edition. McGraw-Hill International

Rosenthal, Stephen R, Effective product design and development, How to cut lead time and increase customer satisfaction, Business One Irwin, Homewood, Illinois 60430, 1992

Yusuf Ismail Nakhoda \& Chorul Saleh, Rancang Bangun Kincir Angin Sumbu Vertikal Pembangkit Tenaga Listrik Portabel, Seminar Nasional Sains dan Teknologi Terapan Vol. 3, Tahun 2015

Zuhal, Zhanggischan.2004. Prinsip Dasar Elektroteknik. Jakarta: PT Gramedia Pustaka Utama 


\section{PERNYATAAN ORISINALITAS KARYA ILMIAH}

Saya yang bertandatangan dibawah ini:

Nama

: Albertus L. Setyabudhi; S.T., M.MT.

Alamat

: Perum. Cipta Diamond no. 01; Batam

Instansi

: Sekolah Tinggi Teknik (STT) Ibnu Sina

No. Identitas (KTP/SIM)

: 3578030204800010

dengan ini menyatakan bahwa karya ilmiah yang akan dipresentasikan dalam Kongres VIII BKSTI

- SNTI dan SATELIT dengan judul:

"Pengembangan Produk Sumber Tenaga Listrik Mini Dengan Pendekatan VDI (Verein Deutscher Ingeniure) 2221"

adalah benar-benar karya asli kami dan belum pernah dipublikasikan dalam bentuk jurnal atau bentuk lain yang dapat dipublikasikan secara umum. Kami akan bersedia menanggung segala konsekuensi jika di kemudian hari ada pihak yang merasa dirugikan dan melakukan tuntutan baik secara pribadi maupun secara hukum.

Demikian pernyataan ini kami buat dengan benar serta penuh tanggung jawab.

Batam, 23 September 2017

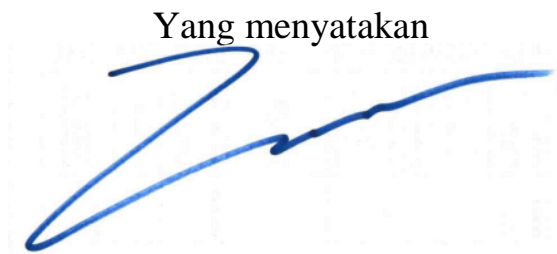

(Albertus L. Setyabudhi, S.T., M.MT) 